\title{
ADVERT ISEMENT*
}

\section{THE WINSTON CHURCHILL MEMORIAL TRUST \\ CHURCHILL FELLOWSHIPS}

\section{TO UNDERTAKE OVERSEAS STUDY PROJECTS}

\section{Objects of the Churchill Trust}

The Winston Churchill Memorial Trust was established in Australia in 1965, the year in which Sir Winston Churchill died. The principal object of the Trust is to perpetuate and honour the memory of Sir Winston Churchill by the award of Memorial Fellowships known as "Churchill Fellowships"。

\section{Function of the Churchill Trust}

The aim of the Churchill Trust is to give opportunity, by the provision of financial support, to enable Australians from all walks of life to undertake overseas study, or an investigative project, of a kind that is not fully available in Australia. This opportunity is provided in furtherance of Sir Winston Churchili's maxim that: "with opportunity comes responsibility".

There are no prescribed qualifications, academic or otherwise, for the award of a Churchill Fellowship. Merit is the primary test, whether based on past achievements or demonstrated ability for future achievement in all walks of life. The value of an applicant's work to the community, and the extent to which it will be enhanced by the applicant's overseas study project are important criteria taken into account in selecting Churchill Fellows. However, Fellowships will not be awarded in cases where the primary purpose of the application is to enable the applicant to obtain higher academic or formal qualifications nor to those in a vocation which offers special opportunity for overseas study.

The Churchil1 Trust gains its income from its capital fund which now stands at over $\$ 8.2 \mathrm{~m}$. The original capital of $\$ 4.2 \mathrm{~m}$. was subscribed, or pledged, in 1965 by all sections of the Australian community to enable the Churchill Trust to be established as a perpetual memorial to Sir Winston Churchill.

\footnotetext{
Published at the request of The Winston Churchill Memorial Trust.
} 
Scope of Churchill Fellowships

Churchill fellows are provided with a return economy-class overseas air-ticket and an Overseas Living Allowance to enable them to undertake their approved overseas study project. In special cases they may also be awarded supplementary allowances including Dependants' Allowance. Fifty seven Churchill Fellowships were awarded for 1983.

All Churchill Fellows are presented, at an appropriate ceremoney with a certificate and badge identifying them as such. The certificate bestows upon the recipient the prestige of being a Churchill Fellow and, while a Fellow is overseas, serves to open many doors that would not otherwise be opened to a private individual.

The Churchill Trust is now (November and December 1982) calling for applications from Australians of 18 years and over, from all walks of 1 ife who wish to be considered for Churchill Fellowships tenable in 1984。

Completed application forms and reports from three referees must reach the Churchill Trust by 28 February 1983.

People wishing to be considered for a Churchill Fellowship should send their name and address NOW with the request for a copy of the Churchill Trust's Information Brochure and application forms to:

The Winston Churchil1 Memorial Trust (M)

P.0.Box 478

Canberra City

ACT 2601 
ALCOHOL AND DRUG EDUCATION IN ABORIGINAL COMMUNITIES PROJECT - (Cont. from $p .28$ )

QUALIFICATIONS: Some knowledge of, or experience in any of the following areas would be an advantage:

i) Queensland Aboriginal Communities

ii) Alcohol and Drugs

iii) Research

iv) Counselling

v) Curriculum Planning

vi) Media

The suitable appointee will be required to travel throughout the State, with a project base in Brisbane. We are looking for a mature person (21 years and over) who can demonstrate a knowledge of Aboriginal culture and lifestyles and who is able to liaise with Aboriginal Communities。

SALARY RANGE: From $\$ 10,000$ p.a. negotiable, plus trave11ing expenses.

TENURE: Three months probation in view of a one year appointment.

CONDITIONS INCLUDE: The payment of travelling expenses. Support from officers of the Alcohol and Drug Education Section, the Indigenous Education Section of this Department and the Queensland Aboriginal and Torres Strait Islander Consultative Committee (QATSICC).

APPLICATIONS: There is no prescribed application form but applications in duplicate giving full personal particulars, age, details of any qualifications held, description of career history, areas of special competence, phone numbers and addresses of two or three referees (one of which should be an Aboriginal/Islander person or organization) should be forwarded together with a telephone number where applicants can be contacted, to:

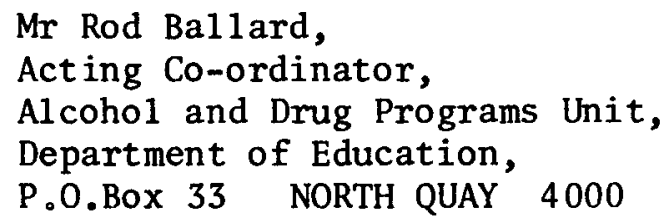

Phone: (07) 2247819

CLOSING DATE: 31 st December, 1982

FURTHER INFORMATION: Available from the above, and Joann Schmider, Aboriginal Education Officer, Phone (07) 2248408 